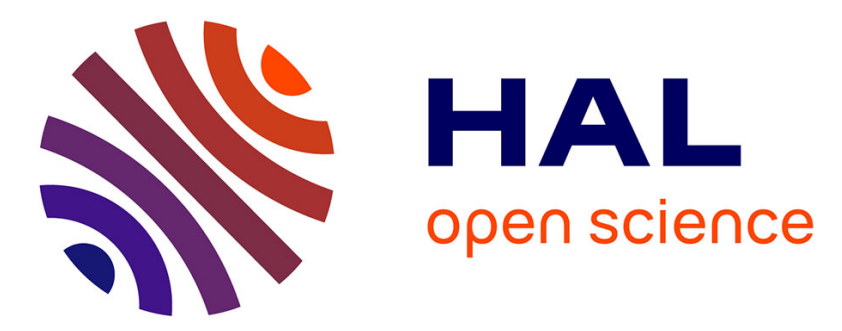

\title{
European glacial dust deposits: Geochemical constraints on atmospheric dust cycle modeling
}

\author{
Denis-Didier Rousseau, Catherine Chauvel, Adriana Sima, Christine Hatté, \\ France Lagroix, Pierre Antoine, Yves Balkanski, Markus Fuchs, Claire \\ Mellett, Masa Kageyama, et al.
}

\section{To cite this version:}

Denis-Didier Rousseau, Catherine Chauvel, Adriana Sima, Christine Hatté, France Lagroix, et al.. European glacial dust deposits: Geochemical constraints on atmospheric dust cycle modeling. Geophysical Research Letters, 2014, 41 (21), pp.7666-7674. 10.1002/2014GL061382 . insu-01351686

\section{HAL Id: insu-01351686 https://hal-insu.archives-ouvertes.fr/insu-01351686}

Submitted on 4 Aug 2016

HAL is a multi-disciplinary open access archive for the deposit and dissemination of scientific research documents, whether they are published or not. The documents may come from teaching and research institutions in France or abroad, or from public or private research centers.
L'archive ouverte pluridisciplinaire HAL, est destinée au dépôt et à la diffusion de documents scientifiques de niveau recherche, publiés ou non, émanant des établissements d'enseignement et de recherche français ou étrangers, des laboratoires publics ou privés. 


\section{Geophysical Research Letters}

\section{RESEARCH LETTER}

10.1002/2014GL061382

Key Points:

- We identify the main aerosol sources for different depositional areas

- The main contributors were regions between 48 and $52^{\circ} \mathrm{N}$, with variable hot spots

- Dust was transported at low elevation and over regional distances only

Supporting Information:

- Readme

- Figure S1

- Figure S2

- Figure S3

- Figure S4

- Table S1

Correspondence to: D.-D. Rousseau,

denis.rousseau@Imd.ens.fr

\section{Citation:}

Rousseau, D.-D., et al. (2014), European glacial dust deposits: Geochemical constraints on atmospheric dust cycle modeling, Geophys. Res. Lett., 41, 7666-7674, doi:10.1002/ 2014GL061382.

Received 30 JUL 2014 Accepted 29 SEP 2014 Accepted article online 1 OCT 2014 Published online 12 NOV 2014

\section{European glacial dust deposits: Geochemical constraints on atmospheric dust cycle modeling}

\author{
Denis-Didier Rousseau ${ }^{1,2}$, Catherine Chauvel ${ }^{3}$, Adriana Sima ${ }^{1}$, Christine Hatté ${ }^{4}$, France Lagroix ${ }^{5}$, \\ Pierre Antoine ${ }^{6}$, Yves Balkanski ${ }^{4}$, Markus Fuchs ${ }^{7}$, Claire Mellett ${ }^{8}$, Masa Kageyama ${ }^{4}$, \\ Gilles Ramstein ${ }^{4}$, and Andreas Lang ${ }^{9}$
}

${ }^{1}$ Ecole Normale Supérieure, Laboratoire de Météorologie Dynamique, UMR8539 CNRS-X-ENS-UPMC and CERES-ERTI, Paris, France, ${ }^{2}$ Lamont-Doherty Earth Observatory, Columbia University, Palisades, New York, USA, ${ }^{3}$ CNRS, Université Grenoble Alpes, Institut des Sciences de la Terre, UMR 5275 CNRS, Grenoble, France, ${ }^{4}$ Laboratoire des Sciences du Climat et de I'Environement, UMR8212 CEA-CNRS-UVSQ, Domaine du CNRS, Gif-sur-Yvette, France, Institut de Physique du Globe de Paris, Sorbonne Paris Cité, Université Paris Diderot, UMR7154 CNRS, Paris, France, ${ }^{6}$ Laboratoire de Géographie Physique, Environnements Quaternaires et Actuels, UMR8591 CNRS, Meudon, France, ${ }^{7}$ Department of Geography, Justus-LiebigUniversity Giessen, Giessen, Germany, ${ }^{8}$ British Geological Survey, Edinburgh, UK, ${ }^{9}$ School of Environmental Sciences, University of Liverpool, Liverpool, UK

Abstract For a long time global paleodust numerical simulations have greatly underestimated dust sources other than modern deserts. Recent modeling experiments incorporating glaciogenic sources of dust have positively improved the agreement between model and paleodust data. This highlights the importance of accurately representing all areas potentially subjected to deflation during an investigated interval. Geochemical results, obtained from European loess sequences collected along a $50^{\circ} \mathrm{N}$ transect, combined with dust emission simulations reveal the geographical distribution of the most important European dust sources between $34 \mathrm{ka}$ and $18 \mathrm{ka}$. We demonstrate that most European dust traveled only a few hundred kilometers or less within the boundary layer from its source before deposition. We conclude that our results encourage acquisition of similar geochemical data for other relevant areas in the world. Further, they could provide critical constraints to benchmark atmospheric models, contributing to improve their performance in simulating dust cycle and associated climate feedbacks.

\section{Present and Past Dust Cycle Modeling}

In modern climate, uncertainties concerning dust emissions are high [Huneeus et al., 2011], but the geographical distribution of the main sources is well known. For past or future climates the uncertainties are even higher, due to potential changes in dust sources which up-to-date models are not able to simulate accurately. This may be a consequence of model biases in simulating precipitation or vegetation cover (resulting in a soil that is too wet or covered with too much snow or vegetation) [Mahowald et al., 2006; Werner et al., 2002], or of an inadequate representation of the inhibiting effect of these variables on dust emissions. The limited spatial resolution of numerical experiments, which in the case of Europe, does not incorporate the complexity of the topography, may also play a role. To correct for these model features, a general circulation model (GCM) study [Mahowald et al., 2006] was proposed introducing glaciogenic sources in six regions of the world (five of which are in the Northern Hemisphere). The glaciogenic source areas correspond to the extensive moraine systems bordering the Northern Hemisphere ice sheets and ice caps, which contributed to global dust emissions in addition to present-day deserts and other barren midlatitude regions. In Mahowald et al. [2006], large areas of alluvial plains where rivers drained meltwater from ice sheets (outwash plains) and mountain glaciers were also included as sources containing dust of glaciogenic origin. Introducing glaciogenic sources increased the simulated dust deposition fluxes for the Last Glacial Maximum (at about $21 \mathrm{ka}$, during sea level lowstand) from 2 to more than 3 times the current values, thus improving the agreement between model and field data. In particular, continental records show huge loess accumulation rates, especially between approximately $40 \mathrm{ka}$ and $18 \mathrm{ka}$.

Studies with an Earth System model of Intermediate Complexity (EMIC), at a lower spatial resolution than a GCM, but with the capacity to run over much longer time intervals, have also incorporated the contribution of dust from glaciogenic areas. One EMIC study has suggested the significant impact of dust on the dynamics of 
the Northern Hemisphere ice sheets [Ganopolski et al., 2010], while another demonstrated the necessity of correctly accounting for variations in the dust source areas and dust emissions for realistically reproducing the spatial and temporal variability of dust deposition over the last $440 \mathrm{ka}$ [Bauer and Ganopolski, 2010].

These studies highlight the importance of accounting for various glaciogenic sources in paleodust simulations. However, the contribution of these sources to deposition of glacial dust could be overestimated in some regions at the expense of nonglaciogenic sources. In Europe, nonglaciogenic areas would have been subject to strong eolian erosion during glacial times, due to reduced vegetation cover and/or a lower sea level, which exposed part of the continental shelf and thus extended the terrestrial landscape west of the present-day continent. Europe is one of the regions where models largely underestimate or even completely miss nonglaciogenic dust sources [Mahowald et al., 1999; Takemura et al., 2009; Werner et al., 2002], and glaciogenic sources are required to totally compensate for their absence [Mahowald et al., 2006].

Here we combine geochemical analyses on dust deposits and results from numerical dust emission simulations for Europe in order to identify dust sources and constraints on dust transport in the atmosphere in this area, as a contribution to understanding subcontinental-scale climate changes.

\section{Data and Methods}

\subsection{European Paleodust Deposits}

The thickest European loess (paleodust) sequences [Antoine et al., 2009; Rousseau et al., 2011, 2007a] are located at $50^{\circ} \mathrm{N}$ latitude. They record the abrupt temperature increases in the North Atlantic area referred to as Dansgaard-Oeschger Events (DOE), identified in Greenland and North Atlantic records [Bond et al., 1992; Johnsen et al., 2001]. In these loess sequences, warm periods called Greenland interstadials (GIS) associated with DOEs corresponded to short intervals of extremely reduced dust deposition permitting soil development. The degree of soil development depends on both the duration and intensity of the corresponding GIS: from embryonic Arctic (gelic gley soils) soils for the shortest ( $<1 \mathrm{ka}$ ) to mature Arctic to boreal brown soils for the longest [Rousseau et al., 2007b, 2011]. In contrast, high-deposition rates and a coarser-grain size distribution characterize the sediments deposited during the cold North Atlantic phases of the Greenland Stadials (GS) including the Last Glacial Maximum (LGM) [Antoine et al., 2009; Rousseau et al., 2007b]. This alternating strong-weak deposition pattern for marine isotope stages 3 and 2 was identified along a $2000 \mathrm{~km}$ West-East transect from Brittany in Northern France to the Dnieper Valley in Ukraine (see Figure 1 and Rousseau et al. [2011]). A general coarsening trend in the grain size from $40 \mathrm{ka}$ to LGM was also observed in loess records over the same transect [Antoine et al., 2009; Rousseau et al., 2011] identifying the LGM as the key period for understanding increased dust emission, transport, and deposition under glacial conditions compared to present day. In addition, it was demonstrated that loess accumulation during this time span resulted from the succession of very intense dust storms (NW winds) leading to coarser loess deposition events [Antoine et al., 2009; Rousseau et al., 2007b]. Such storms were favored by the atmospheric circulation changes associated with (and mainly due to) the Northern Hemisphere ice sheets reaching their (Last Glacial) maximum size [Pausata et al., 2011].

Bulk LGM loess samples were analyzed from reference sequences located along the $50^{\circ} \mathrm{N}$ transect, chosen to represent the geographic and petrographic variability (Figure 1 and Figure S1). The sample suite was complemented with same age sediment from the English Channel and from a loess sequence in Surduk (Serbia, $45^{\circ} 4^{\prime} \mathrm{N}, 20^{\circ} 20^{\prime} \mathrm{E}$ ). Further samples aged between $34 \mathrm{ka}$ and $18 \mathrm{ka}$ [Rousseau et al., 2007b] from the Nussloch reference sequence in the Rhine Valley [Antoine et al., 2001, 2009; Rousseau et al., 2007a, 2011] were included to evaluate temporal changes in source area.

\subsection{Isotopic Analysis}

Samples were crushed in an agate mortar and trace element concentrations as well as $\mathrm{Sr}$ and $\mathrm{Pb}$ isotopes were measured following Chauvel et al. [2011]. Reproducibility for trace element analyses is better than 5\% (based on repeat measurements; see Table S1), and the accuracy is also better than $5 \%$, based on the analyses of international rock standards (JSD2, G2, RGM1, and BR24; see Table S1). Lead and strontium were analyzed after dissolution of the powder and without leaching procedure. Blanks run in parallel with the samples during the course of this work were less than $80 \mathrm{pg}$ of $\mathrm{Pb}$ and $250 \mathrm{pg}$ of $\mathrm{Sr}$ for the entire chemical separation procedure. These amounts are negligible relative to the amount of $\mathrm{Pb}$ and $\mathrm{Sr}$ present in the beakers after 


\section{QAGU Geophysical Research Letters}

0

10

20

30

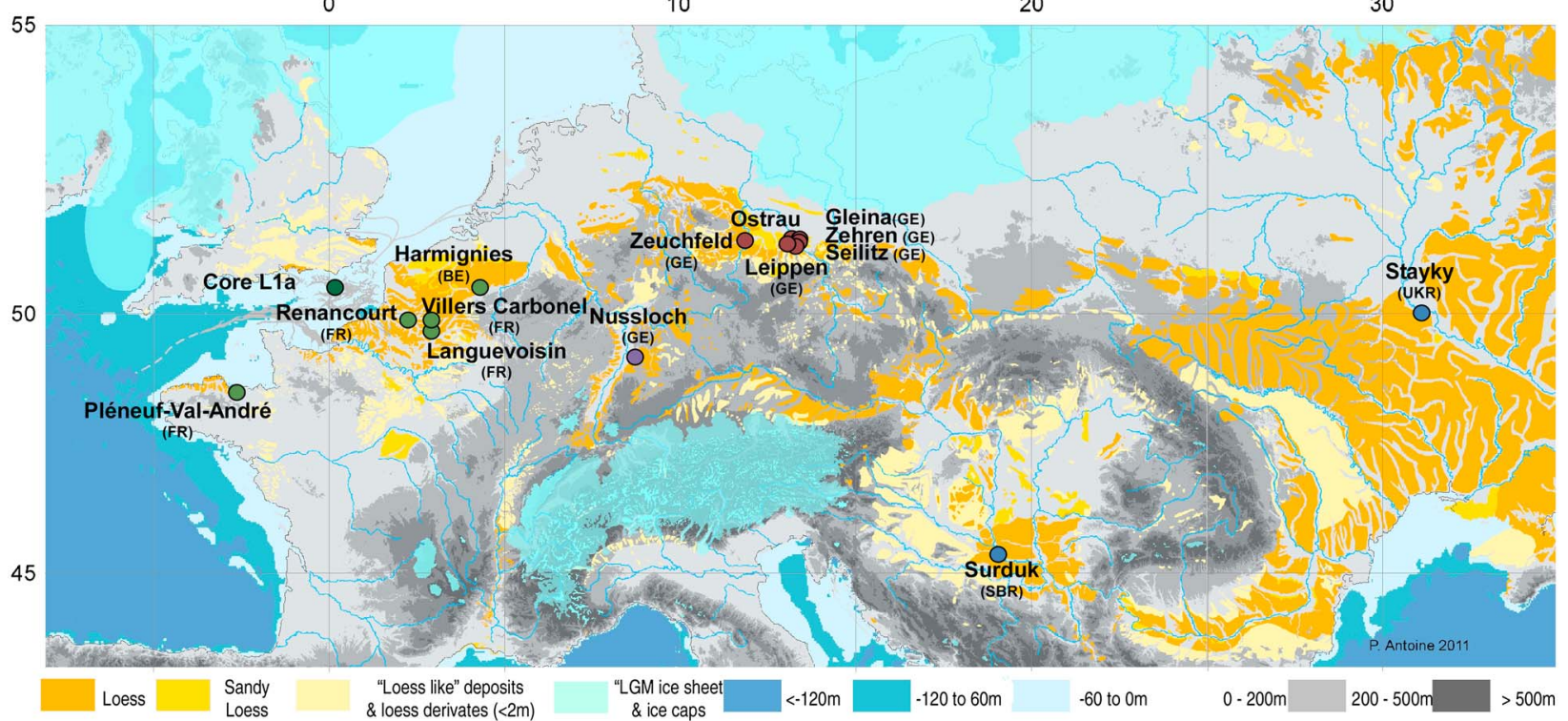

Figure 1. Map of European loess deposits indicating sampling (after Rousseau et al. [2013] and Antoine et al. [2013] modified) with LGM: Last Glacial Maximum; BE: Belgium; FR: France; GE: Germany; SBR: Serbian Republic; UKR: Ukraine; Core L1a from Mellett et al. [2013]. The colors of the bullets for individual sites are grouped according to regions and are used throughout the paper to differentiate between these different regions.

isolation of pure $\mathrm{Pb}$ and $\mathrm{Sr}$ (typically, $600 \mathrm{ng}$ of $\mathrm{Pb}$ and $4 \mu \mathrm{g}$ of $\mathrm{Sr}$ ). Lead isotopic compositions were measured at ENS Lyon using the Nu MultiCollector-Inducted Coupled Plasma - Mass Spectrometer (MC-ICP-MS) and TI addition technique [Chauvel et al., 2011] together with standard bracketing using the standard NBS 981 after every third sample, and the values recommended by Galer and Abouchami [1998]. Strontium isotope ratios were measured in static mode using a Triton TIMS in Brest during two different sessions in 2011 and 2012. To prevent any bias associated with a difference in ${ }^{87} \mathrm{Sr} /{ }^{86} \mathrm{Sr}$ measured on the NBS987 $(0.710249 \pm 5$ and $0.710270 \pm 2$ ), all isotopic compositions have been normalized to a ratio of 0.710260 for NBS987.

\subsection{Modeling}

The numerical results used here are thoroughly presented and discussed in Sima et al. [2009, 2013]. The simulations were performed with the LMDZ (atmosphere) [Hourdin et al., 2006]-ORCHIDEE (land surface and vegetation) [Krinner et al., 2005] configuration of the Institut Pierre-Simon Laplace (IPSL) Earth System model [Marti et al., 2010], and dust emission fluxes were calculated offline using the simulated meteorological and surface conditions. Sea surface temperatures were prescribed, as well as the ice sheet elevation and extent. A stretched grid was used, with finer resolution over Europe (down to $60 \mathrm{~km}$ on Western Europe). The simulations were designed to investigate the climate and dust emission differences between a reference glacial cold state ("GS" for "Greenland stadial") and a warm perturbation ("GIS" for "Greenland interstadial"). The average surface air temperature in the GS experiment shows strong latitudinal gradients due to the presence of the Eurasian ice sheet and the Alpine ice cap (Figure S4a). The longitudinal temperature gradient is less pronounced [Sima et al., 2009]. The annual precipitation, in contrast, shows a longitudinal gradient (Figure S4b) corresponding to the influence of the simulated westerlies [Sima et al., 2009, 2013] (Figure S4c). Such patterns are consistent with observations from loess sequences along the $50^{\circ} \mathrm{N}$ transect [Antoine et al., 2009; Hatté et al., 2013; Rousseau et al., 2007b, 2011]. All loess sequences exhibit a temporal pattern of alternating paleosols and loess units, the characteristics of each paleosol depending on the longitudinal location [Rousseau et al., 2011]. The precipitation/moisture gradient across the European loess belt, with moist conditions in the West, and dryer, more continental conditions toward the East, is also supported by other field observations including polygonal ice wedge networks in Western Europe [Bertran et al., 2013], the photosynthetic gradient in the vegetation inferred from stable C isotopes [Hatté et al., 2013], and evidence from malacofaunas [Rousseau et al., 1990]. The simulated average wind field over Europe shows a westerly flow that can be correlated with the gradients in deposition rate previously mentioned. During stadial conditions, the highest values $(>10 \mathrm{~m} / \mathrm{s}$ ) are observed over Western and Central Europe 
(west of $16^{\circ}$ East; Figure S4c), while interstadial conditions are characterized by lower wind speeds (Figures S4d-S4f).

\section{Tracing Paleodust Sources}

Trace element concentrations measured for all samples are listed in Table S1 in the supporting information.

The samples have relatively uniform trace element patterns (Figure S2) similar to average values for the upper continental crust (Figure S2). As with other periglacial loess samples [Barth et al., 2000; Chauvel et al., 2014; Rudnick and Gao, 2003; Taylor et al., 1983], positive Zr-Hf anomalies are observed due to an excess of zircon indicative of short-distance transport (Figure S2). Lead and strontium isotopic compositions are also listed in Table S1 in the supporting information and shown in Figures S3a-S3c in the supporting information. Sr isotopic compositions of the Western European loess samples form a separate cluster with a slope corresponding to an age of about $365 \mathrm{Ma}$, while the slopes defined by the other samples correspond to $\approx 295 \mathrm{Ma}$ or $485 \mathrm{Ma}$ (Figure S3a). All ages are consistent with the Hercynian to Moldanubian ages of the last orogeny in Northern and Western Europe [Matte, 2001; von Raumer et al., 2003] (Figure S1), but each cluster differs significantly from the others. The initial ratios of each of the three groups also differ, indicating different sediment sources. $\mathrm{Pb}$ isotope ages are much older due to the stronger impact of recycled crustal material on this isotopic system: Western European loess samples define an age of $\approx 1 \mathrm{Ga}$, while age clusters for loess from Nussloch and Eastern Germany are significantly older (Figure S3b). Extrapolation of the Pb-Pb isotope values (see Figures S3b and S3c) again demonstrates that the loess sources of Nussloch, Western Europe, and Eastern Germany are not identical as they have different initial ratios.

The trace element data as well as the $\mathrm{Sr}$ and $\mathrm{Pb}$ isotopic data demonstrate that the sources of the loess/paleodust deposits are proximal and different for each geographical region. Had the main source of dust been located far from the deposition area, only the finer and lighter particles would be transported over long distances and heavy minerals such as zircon would be underrepresented [Chauvel et al., 2014]. Long distance transport also mixes dust from different source regions, and the isotopic variability observed would not be preserved. As shown in Figure S3, differing model ages link loess samples to sources in Western Europe, the Rhine Valley, East Germany, western Ukraine, and Serbia (Figure S1) that are located less than a few hundred kilometers from deposition areas. The numerical experiments performed with the IPSL climate model for European glacial episodes (see section 2.3) support these findings. The simulations were designed for an earlier period than the LGM, at the beginning of the main European loess deposition period (at about $40 \mathrm{ka}$ ), when the Fennoscandian ice sheet margin was north of $54^{\circ} \mathrm{N}$ [Lambeck et al., 2010]. They show dust emissions mainly occurring in the latitudinal band 48 to $53^{\circ} \mathrm{N}$ (see Figure 2 and supporting information) [Sima et al., 2009, 2013]. The simulated sources are nonglaciogenic: they correspond to eolian erosion occurring where strong winds meet reduced soil moisture and vegetation cover, and are thus strongly seasonal in nature. In the GS experiment, designed to represent a Greenland stadial environment, with high dust deposition rates [Antoine et al., 2009; Rousseau et al., 2007b, 2011], large areas of the present North Sea and English Channel, that emerged between $60 \mathrm{ka}$ and $18 \mathrm{ka}$ ago [Siddall et al., 2008], acted as effective deflation areas (Figures 1 and 2a). Relatively high emission fluxes are also calculated for the European northern plain (Figure 2a). In contrast, the simulated dust emissions are significantly lower in the corresponding "interstadial" experiment GIS (Figure 2b). This is in agreement with the various observed soils developed on top of individual loess/paleodust deposits during the relatively warm interstadial periods. After 40 ka, the northern limit of the latitudinal band potentially exposed to deflation would have varied with the phases of advance and retreat of the Eurasian ice sheet southern margin [Svendsen et al., 2004]. During the LGM, deflation would be confined between the Eurasian ice sheet at its maximum extent and the high relief of the Alps ice cap and the Carpathians (Figure 1).

Eolian erosion may produce a wide range of particle sizes that are transported for distances that depend mainly on the particle's size, weight, and shape, and the wind strength. In the few European sequences for which grain size resolved mass distributions are available for the period of interest, there are $22-25 \%$ of clay $(<2 \mu \mathrm{m}), 15-30 \%$ of fine silt $(2-20 \mu \mathrm{m}), 40-50 \%$ of coarse silt $(20-50 \mu \mathrm{m})$, and $7-10 \%$ of sand $(>50 \mu \mathrm{m})$ [Antoine et al., 1999, 2001; Rousseau et al., 2011]. The coarsest material (coarse silt and sand) is mainly derived from local sources within tens of kilometers transport distances, a feature consistent with Pye [1987]. Some of the thickest aeolian deposits are located along rivers such as the Rhine, Danube, and 
A) Dust emission flux for the Greenland Stadial

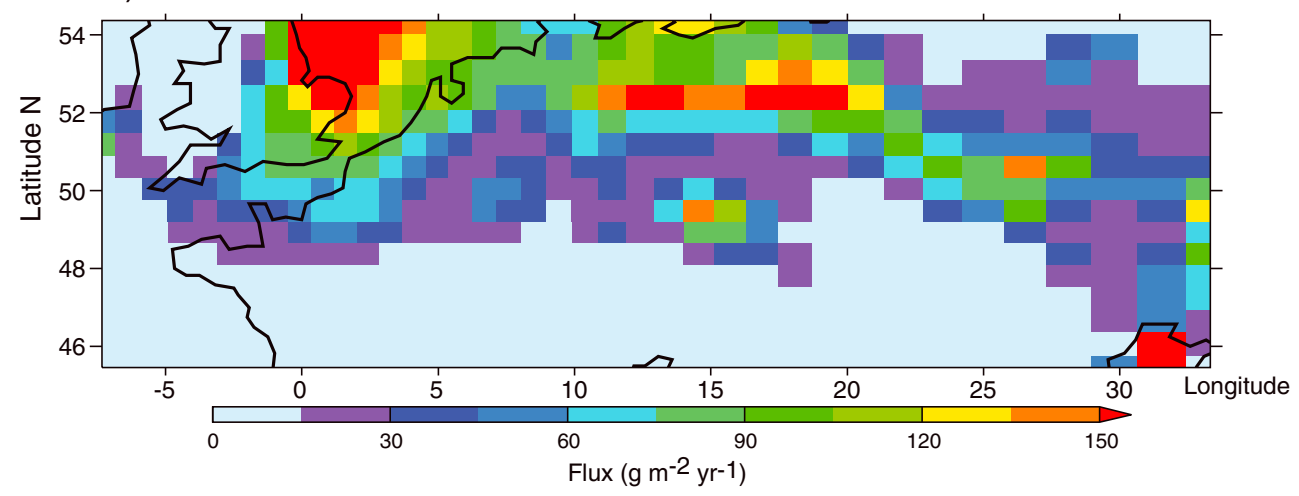

B) Ratio of dust emission fluxes between Greenland Interstadial (GIS) and Stadial (GS)

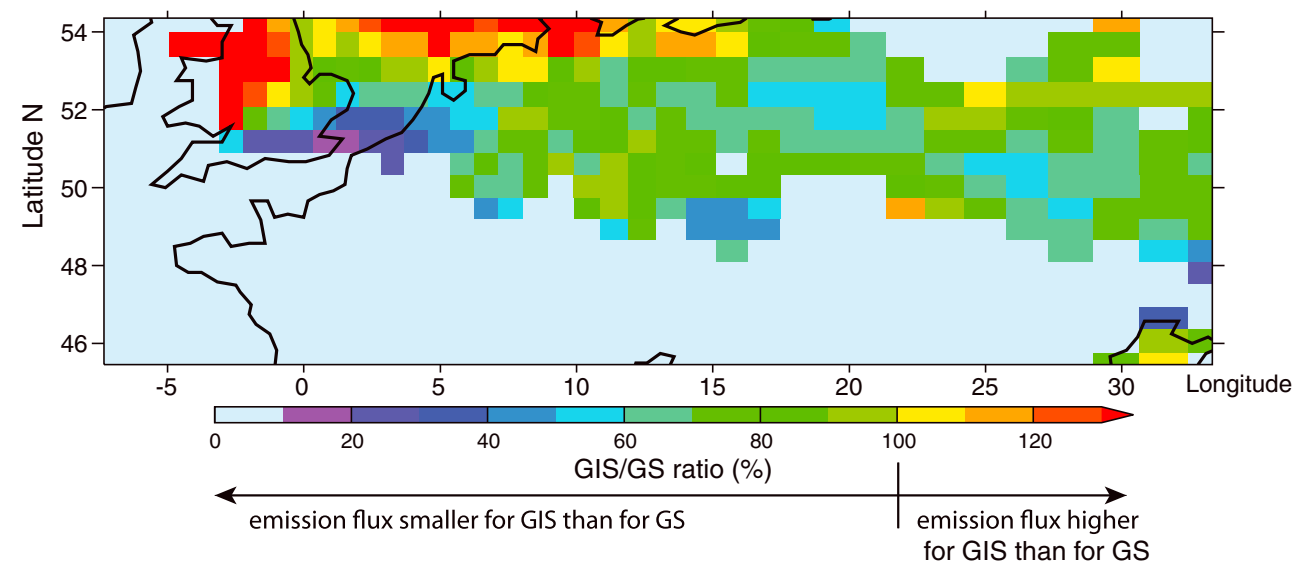

Figure 2. Reconstruction of dust fluxes (F) $\left(\mathrm{g} \mathrm{m}^{-2} \mathrm{yr}^{-1}\right)$ over Europe. Fluxes for two climate conditions. (a) Flux during reference stage, i.e., Greenland stadial (GS) and LGM, and (b) ratio of dust fluxes between Greenland interstadial (GIS) and Greenland stadial (GS) expressed as percent.

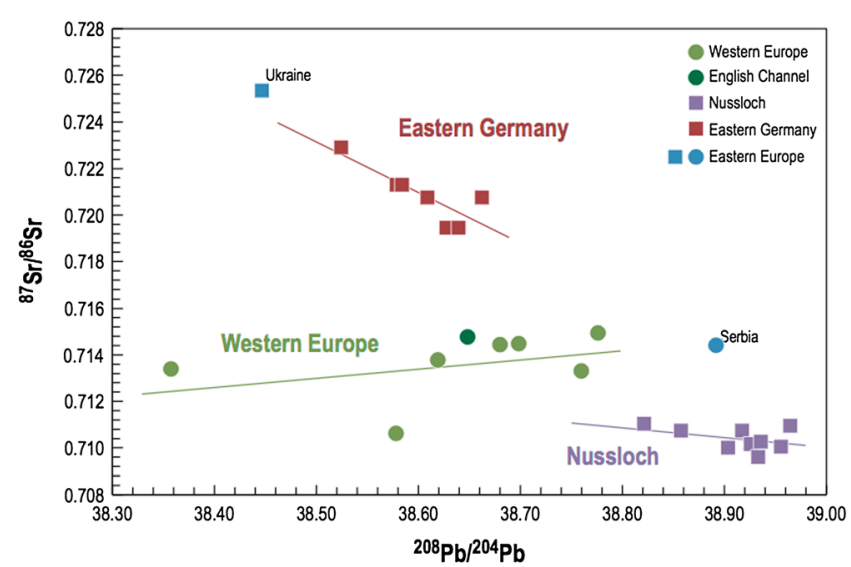

Figure 3. Isotope ratios ${ }^{87} \mathrm{Sr} /{ }^{86} \mathrm{Sr}$ plotted versus ${ }^{208} \mathrm{~Pb} /{ }^{204} \mathrm{~Pb}$; errors on measurements are smaller than the symbols. Samples from Western Europe, Nussloch, and Eastern Germany define distinct groups that can easily be distinguished. For each geographical group linear regressions are shown. The sample originating from the English Channel plots well within the Western Europe loess deposits. Also shown are isotope ratios for loess deposits from Eastern Europe.
Rhône, which at the time were wide periglacial braided river systems regularly supplying sediment during snow and ice melting periods and acting as deflation areas when river flow was largely diminished or absent [Rousseau et al., 2007a]. In addition, the occurrence in LGM loess deposits of coarse sand particles derived from Tertiary bedrock [Antoine et al., 2003], braided alluvial plains [Antoine et al., 2009], or chalk grains (2-4 mm) reworked from limestone bedrocks [Antoine et al., 1999], demonstrates the importance of extremely local deflation processes (e.g., a few hundred meters). For the size range below $2 \mu \mathrm{m}$, numerical simulations for the LGM [Mahowald et al., 2006] suggest that such fine particles originating from 


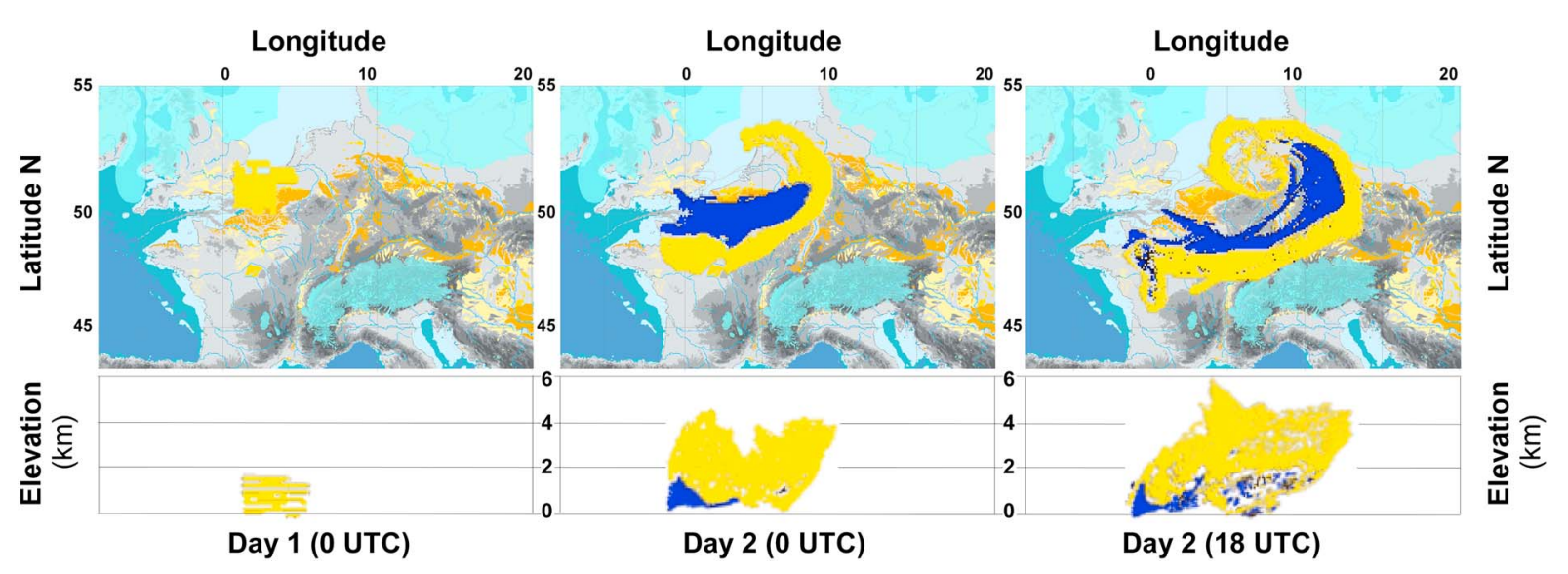

Figure 4. A 3-D conceptual representation of a dust storm in Europe leading to loess deposit development during the LGM. The sketch is constructed by analogy with the two exceptional dust storms in China in April 2001, one (in blue) starting $12 \mathrm{~h}$ after the other (in yellow). (top row) The forward trajectory particles from northern Chinese deserts contributing to those events [after Jaffe et al., 2003] are scaled and superimposed in Figure 1 to represent snapshots during a single event starting in the English Channel. (bottom row) The dust emission and transport in vertical section. The left panel corresponds to day 1-0 UTC, the middle one to day 2-0 UTC, and the right panel to day 2-18 UTC.

Europe were transported over thousands of kilometers, to northern Asia and Greenland [Mahowald et al., 2011], although no traces of European dust have yet been reported in Greenland ice cores [Svensson et al., 2000]. For the medium-size (silt) particles $(2-50 \mu \mathrm{m})$ the transport distances must have been intermediate between tens and thousands of kilometers. The isotopic analyses presented here help to better constrain this transport range for the LGM in Europe. We note that most numerical transport and deposition models (including that employed by Mahowald et al. [2006, 2011]) only deal with particles generally below $10 \mu \mathrm{m}$ diameter [Huneeus et al., 2011], which have an atmospheric residence time long enough to play a nonnegligible role in the aerosol-climate feedbacks. However, coarser particles which contribute considerably more to the loess mass should be taken into account in future studies for a more meaningful comparison to loess data.

\section{Regional Origin of European Paleodust and the Global Challenge}

The bulk sediments on which our analyses have been performed were composed of at least 75\% (in mass) of particles $>2 \mu \mathrm{m}$. These particles therefore must originate from regional sources within hundreds of kilometers. This implies transport at relatively low elevations, probably in the atmospheric boundary layer typically between 300 and 1000 m, as observed in present-day major dust storms. Our analyses also provide strong constraints on the origin of the finest particles that represent the other about $25 \%$ of the sediment mass. If they were transported over long distances, they would be well mixed and all loess deposits would share a common component and the clusters defined by each geographical location (Figure 3 and Figures S3a-S3c) would overlap at the composition of the common end-member. This is clearly not the case here as shown in Figures 3 and S3a-S3C in the supporting information, instead clusters are essentially subparallel.

The isotopic data preclude that the fine particles are derived from a well-mixed atmospheric reservoir and show that they originate from essentially the same source as the larger particles. A small, insignificant contribution from remote sources like North Africa [Mahowald et al., 2011], however, cannot be excluded. Considering the temporal variability, the data also show that the source of dust deposited in the Rhine Valley remained unchanged between 34 and 18 ka (Figure 3).

We are thus able to show that European loess deposits are the cumulative result of past dust storms (Figure 4) that incorporated dust over local to regional distances. This is similar to loess deposits from the U.S. Great Plains and China, for which provenance data also indicate relatively short-distance transport of hundreds of kilometers [Aleinikoff et al., 2008; Muhs et al., 2008; Stevens et al., 2013]. In Europe, the most important deposits, located around $50^{\circ} \mathrm{N}$, originate from distinct source areas in a corridor between the Eurasian ice sheet and the high relief of the Alps ice cap and the Carpathians. The main dust transport occurred in the atmospheric boundary layer and over short time periods only, in agreement with the conceptual model 
[Antoine et al., 2009] linking loess deposition events to the development of individual dust storms over Western Europe (Figure 4). Further modeling results might show if dust emission events were spatially and temporarily distinct, as in China in 2001 (case adapted in Figure 4), or if they occurred simultaneously across larger regions, as in Australia in 2009. Earth surface conditions during glacial times certainly allowed for both types of events. However, no available data allow yet verifying this type of result.

\section{Conclusion}

For the European loess deposits located between $48^{\circ} \mathrm{N}$ and $52^{\circ} \mathrm{N}$, the main dust contributors were in the same latitudinal band, with variable hot spots depending on climate conditions. Dust was transported at low elevation and over regional distances only. New challenges will be to acquire more detailed geochemical data allowing to trace the origin of the different size fractions for the European loess deposits and to extend this type of analyses to other loess deposits worldwide. We will then be able to better constrain the provenance of eolian dust globally. This will contribute to represent the dust sources in future numerical simulations of the dust cycle more adequately. Taking into account as accurately as possible the changes of the Earth surface during glacial climates, such as the exposure of shelf areas due to sea level lowering, the evolution of outwash plain morphology, zonal shifts in vegetation with extensive areas of tundra and bare soil, and seasonal variations in vegetation and soil moisture, will be the key.

Finally, the results presented here for Europe might be used as a benchmark to test atmospheric models. They open up a more precise quantification of dust impact (i) on total radiative forcing of the atmosphere, which has long been impeded by the unconstrained atmospheric residence times of dust [Boucher et al., 2013], (ii) on ice sheet development, and (iii) continental albedos during the last climate cycle. Improving models of the mineral aerosol cycle on the basis of well constrained geochemical data from reference series is a necessary prerequisite to apprehend the dust impact on past climates, reduce model uncertainties, and improve present and future model predictions.

\section{Author contributions}

D.D.R. designed the study, led the field works, and the writing of this paper. C.C. performed the isotopic analysis, AS performed the modeling with M.K., G.R., and Y.B. P.A., C.H., F.L., M.F., and C.M. provided samples and performed field work of sequences cited in the manuscript. C.H. conducted the $C^{14}$ dating of the sequences, M.F. and A.L. the OSL ones. All authors contributed to the discussion, interpretation of the results, and the writing of the manuscript.

Acknowledgments

We would like to thank Sarah Bureau, Philippe Telouk, and Philippe Nonnotte for their help during the analytical work as well as Peter Clark, Nick Arndt, Jerry McManus, and Gisela Winckler for usefu comment on drafts of this manuscript. Joe Mason and an anonymous reviewer also provided very useful comments that helped improve the content and clarity of the manuscript. This work was supported by the French ANR through grant ANR-08-BLAN-0227 to PI D.D.R., and completed during a Visiting Professorship to Columbia University by D.D.R. supported by the Alliance program. The simulations have been performed using High Performance Computing resources of the Commissariat à l'Energie Atomique, France. This is contribution 7833 of Lamont-Doherty Earth Observatory, 4444 of LSCE, and 3572 of IPGP.

Geoffrey Tyndall thanks Joe Mason and one anonymous reviewer for their assistance in evaluating this paper.

\section{References}

Aleinikoff, J. N., D. R. Muhs, E. A. Bettis, W. C. Johnson, C. M. Fanning, and R. Benton (2008), Isotopic evidence for the diversity of late Quaternary loess in Nebraska: Glaciogenic and nonglaciogenic sources, Geol. Soc. Am. Bull., 120, 1362-1377.

Antoine, P., D. D. Rousseau, J. P. Lautridou, and C. Hatté (1999), Last interglacial-glacial climatic cycle in loess-paleosol successions of north-western France, Boreas, 28, 551-563.

Antoine, P., D. D. Rousseau, L. Zöller, A. Lang, A. V. Munaut, C. Hatté, and M. Fontugne (2001), High-resolution record of the last interglacialglacial cycle in the loess palaeosol sequences of Nussloch (Rhine Valley-Germany), Quat. Int., 76/77, 211-229.

Antoine, P., J. J. Bahain, N. Debenham, M. Frechen, A. Gauthier, C. Hatté, N. Limondin-Lozouet, J. L. Locht, P. Raymond, and D. D. Rousseau (2003), Nouvelles données sur le Pleistocène du nord du Bassin Parisien: Les séquences loessiques de Villiers-Adam (Val d'Oise, France), Quaternaire, 14(4), 219-235.

Antoine, P., D. D. Rousseau, O. Moine, S. Kunesch, C. Hatte, A. Lang, H. Tissoux, and L. Zoller (2009), Rapid and cyclic aeolian deposition during the Last Glacial in European loess: A high-resolution record from Nussloch, Germany, Quat. Sci. Rev., 28(25-26), 2955-2973, doi:10.1016/ J.Quascirev.2009.08.001.

Antoine, P., et al. (2013), High-resolution record of the environmental response to climatic variations during the Last Interglacial-Glacia cycle in Central Europe: The loess-palaeosol sequence of Dolní Věstonice (Czech Republic), Quat. Sci. Rev., 67, 17-38, doi:10.1016/ j.quascirev.2013.01.014.

Barth, M. G., W. F. McDonough, and R. L. Rudnick (2000), Tracking the budget of Nb and Ta in the continental crust, Chem. Geol., 165(3-4), 197-213, doi:10.1016/S0009-2541(99)00173-4.

Bauer, E., and A. Ganopolski (2010), Aeolian dust modeling over the past four glacial cycles with CLIMBER-2, Global Planet. Change, 74(2), 49-60, doi:10.1016/j.gloplacha.2010.07.009.

Bertran, P., et al. (2013), Distribution and chronology of Pleistocene permafrost features in France: Database and first results, Boreas, doi:10.1111/bor.12025.

Bond, G., et al. (1992), Evidence for massive discharges of icebergs into the North Atlantic Ocean during the last glacial period, Nature, 360 , 245-249. 
Boucher, O., et al. (2013), Clouds and Aerosols, in Climate Change 2013: The Physical Science Basis. Contribution of Working Group I to the Fifth Assessment Report of the Intergovernmental Panel on Climate Change, edited by T. F. Stocker et al., pp. 571-657, Cambridge Univ. Press, Cambridge, U. K., and New York.

Chauvel, C., S. Bureau, and C. Poggi (2011), Comprehensive chemical and isotopic analyses of basalt and sediment reference materials, Geostand. Geoanal. Res., 35(1), 125-143, doi:10.1111/j.1751-908X.2010.00086.x.

Chauvel, C., M. Garçon, S. Bureau, A. Besnault, B.-M. Jahn, and Z. L. Ding (2014), Constraints from loess on the Hf-Nd isotopic composition of the upper continental crust, Earth Planet. Sci. Lett., 388, 48-58, doi:10.1016/j.epsl.2013.11.045.

Galer, S. J. G., and W. Abouchami (1998), Practical application of lead triple spiking for correction of instrumental mass discrimination, Mineral. Mag., 62A, 491-492.

Ganopolski, A., R. Calov, and M. Claussen (2010), Simulation of the last glacial cycle with a coupled climate ice-sheet model of intermediate complexity, Clim. Past, 6(2), 229-244.

Hatté, C., C. Gauthier, D. D. Rousseau, P. Antoine, M. Fuchs, F. Lagroix, S. Markovic, O. Moine, and A. Sima (2013), Excursions to C4 vegetation recorded in the Upper Pleistocene lœss of Surduk (Northern Serbia): An organic isotope geochemistry study, Clim. Past, 9, 1001-1014, doi:10.5194/cp-9-1001-2013.

Hourdin, F., et al. (2006), The LMDZ4 general circulation model: Climate performance and sensitivity to parametrized physics with emphasis on tropical convection, Clim. Dyn., 27, 787-813, doi:10.1007/s00382-006-0158-0.

Huneeus, N., et al. (2011), Global dust model intercomparison in AeroCom phase I, Atmos. Chem. Phys., 11(15), 7781-7816, doi:10.5194/ acp-11-7781-2011.

Jaffe, D., J. Snow, and O. Cooper (2003), The 2001 Asian dust events: Transport and impact on surface aerosol concentrations in the US, Eos, 84(46), 501-507, animated supplement.

Johnsen, S. J., D. Dahl-Jensen, N. Gundestrup, J. P. Steffensen, H. B. Clausen, H. Miller, V. Masson-Delmotte, A. E. Sveinbjörnsdottir, and J. White (2001), Oxygen isotope and palaeotemperature records from six Greenland ice-core stations: Camp Century, Dye-3, GRIP, GISP2, Renland and NorthGRIP, J. Quat. Sci., 16(4), 299-307.

Krinner, G., N. Viovy, N. de Noblet-Ducoudre, J. Ogee, J. Polcher, P. Friedlingstein, P. Ciais, S. Sitch, and I. C. Prentice (2005), A dynamic global vegetation model for studies of the coupled atmosphere-biosphere system, Global Biogeochem. Cycles, 19, GB1015, doi:10.1029/2003GB002199.

Lambeck, K., A. Purcell, J. Zhao, and N. O. Svensson (2010), The Scandinavian Ice Sheet: From MIS 4 to the end of the Last Glacial Maximum, Boreas, 39(2), 410-435, doi:10.1111/j.1502-3885.2010.00140.x.

Mahowald, N., K. Kohfeld, M. Hansson, Y. Balkanski, S. P. Harrison, I. C. Prentice, M. Schulz, and H. Rodhe (1999), Dust sources and deposition during the last glacial maximum and current climate: A comparison of model results with paleodata from ice cores and marine sediments, J. Geophys. Res., 104, 15,895-15,916, doi:10.1029/1999JD900084.

Mahowald, N., S. Albani, S. Engelstaedter, G. Winckler, and M. Goman (2011), Model insight into glacial-interglacial paleodust records, Quat. Sci. Rev., 30(7-8), 832-854, doi:10.1016/j.quascirev.2010.09.007.

Mahowald, N. M., D. R. Muhs, S. Levis, P. J. Rasch, M. Yoshioka, C. S. Zender, and C. Luo (2006), Change in atmospheric mineral aerosols in response to climate: Last glacial period, preindustrial, modern, and doubled carbon dioxide climates, J. Geophys. Res., 111, D10202, doi:10.1029/2005JD006653.

Marti, O., et al. (2010), Key features of the IPSL ocean atmosphere model and its sensitivity to atmospheric resolution, Clim. Dyn., 34, 1-26, doi:10.1007/s00382-009-0640-6.

Matte, P. (2001), The Variscan collage and orogeny (480-290 Ma) and the tectonic definition of the Armorica microplate: A review, Terra Nova, 13(2), 122-128, doi:10.1046/j.1365-3121.2001.00327.x.

Mellett, C. L., D. M. Hodgson, A. J. Plater, B. Mauz, I. Selby, and A. Lang (2013), Denudation of the continental shelf between Britain and France at the glacial-interglacial timescale, Geomorphology, 203, 79-96, doi:10.1016/j.geomorph.2013.03.030.

Muhs, D. R., E. A. Bettis, J. N. Aleinikoff, J. P. McGeehin, J. Beann, G. Skipp, B. D. Marshall, H. M. Roberts, W. C. Johnson, and R. Benton (2008), Origin and paleoclimatic significance of late Quaternary loess in Nebraska: Evidence from stratigraphy, chronology, sedimentology, and geochemistry, Geol. Soc. Am. Bull., 120, 1378-1407.

Pausata, F. S. R., C. Li, J. J. Wettstein, M. Kageyama, and K. H. Nisancioglu (2011), The key role of topography in altering North Atlantic atmospheric circulation during the last glacial period, Clim. Past, 7, 1089-1101, doi:10.5194/cp-7-1089-2011.

Pye, K. A. (1987), Aeolian Dust and Dust Deposits, Academic Press, London.

Rousseau, D. D., J. J. Puisségur, and J. P. Lautridou (1990), Biogeography of the Pleistocene pleniglacial malacofaunas in Europe-Stratigraphic and climatic implications, Palaeogeogr. Palaeoecol., 80(1), 7-23.

Rousseau, D. D., E. Derbyshire, P. Antoine, and C. Hatté (2007a), European loess records, in Encyclopedia of Quaternary Science, edited by S. Elias, pp. 1440-1456, Elsevier, Amsterdam.

Rousseau, D. D., A. Sima, P. Antoine, C. Hatte, A. Lang, and L. Zöller (2007b), Link between European and North Atlantic abrupt climate changes over the last glaciation, Geophys. Res. Lett., 34, L22713, doi:10.1029/2007GL031716.

Rousseau, D. D., P. Antoine, N. Gerasimenko, A. Sima, M. Fuchs, C. Hatte, O. Moine, and L. Zoeller (2011), North Atlantic abrupt climatic events of the last glacial period recorded in Ukrainian loess deposits, Clim. Past, 7(1), 221-234, doi:10.5194/cp-7-221-2011.

Rousseau, D. D., M. Ghil, G. Kukla, A. Sima, P. Antoine, M. Fuchs, C. Hatté, F. Lagroix, M. Debret, and O. Moine (2013), Major dust events in Europe during marine isotope stage 5 (130-74 ka): A climatic interpretation of the "markers", Clim. Past, 9, 2213-2230, doi:10.5194/ cp-9-2213-2013.

Rudnick, R. L., and S. Gao (2003), 3.01-Composition of the continental crust, in Treatise on Geochemistry, edited by D. H. Heinrich and K. T. Karl, pp. 1-64, Pergamon, Oxford, U. K., doi:10.1016/B0-08-043751-6/03016-4.

Siddall, M., E. J. Rohling, W. G. Thompson, and C. Waelbroeck (2008), Marine isotope stage 3 sea level fluctuations: Data synthesis and new outlook, Rev. Geophys., 46, RG4003, doi:10.1029/2007RG000226.

Sima, A., D. D. Rousseau, M. Kageyama, G. Ramstein, M. Schulz, Y. Balkanski, P. Antoine, F. Dulac, and C. Hatte (2009), Imprint of North-Atlantic abrupt climate changes on western European loess deposits as viewed in a dust emission model, Quat. Sci. Rev., 28(25-26), 2851-2866, doi:10.1016/j.quascirev.2009.07.016.

Sima, A., M. Kageyama, D. D. Rousseau, G. Ramstein, Y. Balkanski, P. Antoine, and C. Hatté (2013), Modeling dust emission response to North Atlantic millennial-scale climate variations from the perspective of East European MIS3 loess deposits, Clim. Past, 9, 1385-1402, doi:10.5194/cpd-9-143-2013.

Stevens, T., A. Carter, T. P. Watson, P. Vermeesch, S. Andò, A. F. Bird, H. Lu, E. Garzanti, M. A. Cottam, and I. Sevastjanova (2013), Genetic linkage between the Yellow River, the Mu Us desert, and the Chinese Loess Plateau, Quat. Sci. Rev., 78, 355-368.

Svendsen, J. I., H. Alexanderson, V. I. Astakhov, I. Demidov, J. A. Dowdeswell, S. Funder, V. Gataullin, M. Henriksen, C. Hjort, and M. Houmark-Nielsen (2004), Late Quaternary ice sheet history of northern Eurasia, Quat. Sci. Rev., 23(11-13), 1229-1271. 
Svensson, A., P. E. Biscaye, and F. E. Grousset (2000), Characterization of late glacial continental dust in the Greenland Ice Core Project ice core, J. Geophys. Res., 105(D4), 4637-4656, doi:10.1029/1999JD901093.

Takemura, T., M. Egashira, K. Matsuzawa, H. Ichijo, R. O'ishi, and A. Abe-Ouchi (2009), A simulation of the global distribution and radiative forcing of soil dust aerosols at the Last Glacial Maximum, Atmos. Chem. Phys., 9, 3061-3073, doi:10.5194/acp-9-3061-2009.

Taylor, S. R., S. M. McLennan, and M. T. McCulloch (1983), Geochemistry of loess, continental crustal composition and crustal model ages, Geochim. Cosmochim. Acta, 47, 1897-1905.

von Raumer, J. F., G. A. Stampfli, and F. Bussy (2003), Gondwana-derived microcontinents-The constituents of the Variscan and Alpine collisional orogens, Tectonophysics, 365(1-4), 7-22, doi:10.1016/s0040-1951(03)00015-5.

Werner, M., I. Tegen, S. P. Harrison, K. E. Kohfeld, I. C. Prentice, Y. Balkanski, H. Rodhe, and C. Roelandt (2002), Seasonal and interannual variability of the mineral dust cycle under present and glacial climate conditions, J. Geophys. Res., 107(D24), 4744, doi:10.1029/ 2002JD002365. 